\title{
Mechanism underlying the inhibitory effect of Elaeagnus Conferta Roxb on TNF - a induced NF- kB nuclear translocation in non- small lung cancer A549 cell line using
Flow cytometry
}

\author{
G.Lalitha*1, Nazeema $\mathrm{TH}^{2}$ \\ ${ }^{1}$ Assistant Professor, Department of Biochemistry, \\ Rathnavel Subramaniam College of Arts and Science, Coimbatore, Tamil Nadu, India. \\ ${ }^{2}$ Principal, Michael Job College of Arts and Science for Women, Coimbatore, Tamil Nadu, India. \\ *Corresponding author E-mail : lalithajune3@gmail.com
}

\begin{abstract}
Our study examined for the inhibitory effect of ethanolic extract of Eleagnus Conferta Roxb leaves on TNF - $\alpha$ induced NF- kB nuclear translocation in lung cancer A549 cell line using flow cytometry. Apoptosis also studied to know about the antiproliferative and anticancer effects. However, our results revealed in apoptosis, Elaeagnus conferta Roxb leaves showed (33.54\%) increased in proportion of cells. In the study of pre-treatment of A549 cells with Elaeagnus conferta Roxb leaves followed by TNF- $\alpha$ caused the increased proportion of cells $(\mathbf{2 0 . 7 8 \%})$ at apoptosis induced cell death, which was statistically significant $(p<0.001)$. The untreated A549 cells had minimal NF-kB expression $(0.25 \pm 0.01 \%)$. However, the approach of A549 cells with Elaeagnus conferta Roxb had induced NF-kB production many fold (11.50 $\pm 1.05 \%)$. Therefore, we conclude our study was proved the impact of Elaeagnus conferta Roxb leaves inhibit the cellular growth of NSCLC-A549 cell line and induces apoptosis. Hence, from our findings, we proved this plant has anticancer activity, further feasibly taken for drug formulation .
\end{abstract}

Keywords : Elaeagnus conferta roxb leaves, apoptosis, TNF $-\alpha, \mathrm{NF}-\mathrm{kB}$ assay.

\section{Introduction}

Elaeagnus conferta roxb leaves known as Silevrberry or oleaster, is a genus of some 50-75 flowering plant species in the Elaeagnaceae family. The majority of this species are endemic to temperate and subtropical Asian areas. These plants are shrubs or small trees of deciduous it consists of evergreen color [1]. Our previous study proved the existence of antioxidant, anticancer activity is present on this species. Though the use of Elaeagnus Conferta Roxb leaves is a traditional medicine, pre-owned in therapy of cancer has been put forward. In evolution of medicine from medicinal plants, the research finding proposed it could increase the life span in cancer patients. The review by the ICMR- Indian Council of Medical Research from 2012- 2016, persons suffering from lung cancer is estimated to be $(83,000$ in men and 31,000 in women) 1.14 lakh and the projected 1.4 lakh new cases may develop in 2020 [2-3]. Major mediator of inflammation develop the transcription factor NF- kB lung cancer [4-5] and is persuaded in response to inflammation and other stimuli. TNF- $\alpha$ could prompt survival of cancer cell and tumor progression. Mainly in tumor cells, it could induce growth, proliferation and metastasis [6]. On the contrary, apoptosis and necrosis has considered as an abnormal cell death. Though necrosis has been characterized by inflammatory response and chemotactic work is found to tissue harm and bacterial infection that has prompted neurotic inflammation that cause to deliver hypoxia, angiogenesis, multiplication and development of the cell signalling factors [7].

Evidences from various researchers has demonstrated that immune inflammatory cells in necrosis could prompt tumor advancing by the creation of EGF, VEGV, proteases cause to angiogenesis and metastasis. The development of malignant tumors is regulated by NF- $\kappa \mathrm{B}$ through a wide characterization of changes such as apoptosis, stress responses, tumorigenesis, which leads to activating signalling cascades such as TNF- $\alpha, \mathrm{Bcl}-2$, caspase pathways [8] though this over expression has to be regulated by medicinal plant in metastasis stage. The majority of cancer cells become resistant to TNF- $\alpha$ as an outcome of the inactivation of NF- kB and consequent induction of anti- apoptotic molecules [9]. Consequently, it is rational to put forward that agents can smother inflammatory arbiters have a potential for both the anticipation and therapy of lung cancer. Hence we examined our research to elucidate mechanism underlying the hindrance effect of Eleagnus Conferta Roxb leaves on TNF $-\alpha$ induced NF- kB nuclear translocation in lung cancer A549 cell line. 


\section{Collection of Plant extract}

\section{Materials and methods}

Eleagnus Conferta Roxb leaves were collected from Annakatti, western ghats, Coimbatore, it was authenticated from Botanical Survey of India, TNAU. No BSI/SRC/5/23/3018/2785/Tech.

\section{Cell lines and Culture medium}

A549-Human lung adenocarnoma cell line was purchased from National Centre for Cell Science (NCCS, Pune), India. Stock cells cultured in DMEM high glucose medium (\#AL111, Himedia) supplemented with 10\% inactivated FBS (\#RM10432, Himedia), Pencillin (100 IU/ml), Streptomycin $(100 \mu \mathrm{g} / \mathrm{ml})$ and amphotericin B (5 $\mu \mathrm{g} / \mathrm{ml}$ ) in a humidified atmosphere of $5 \% \mathrm{CO}_{2}$ at $37^{\circ} \mathrm{C}$ until confluent. Cells were dissociated with a TPVG solution $\left(0.2 \%\right.$ trypsin, $0.02 \%$ EDTA, $0.05 \%$ Glucose in PBS). Stock cultures were grown in $25 \mathrm{~cm}^{2}$ culture flasks and all experiments were carried out in $60 \mathrm{~mm}$ petri plates (Torsons India Pvt. Ltd., Kolkata, India).

\section{Detection of apoptosis and necrosis (Annexin V PI staining)}

EEC used to induce cell apoptosis and necrosis of A549 lung cancer cell line was quantified by Annexin V and PI uses flow cytometry. Six culture cell plate was incubated with treatment EEC ( $5 \mu 1)$, Standard Camptothecin $(75 \mu \mathrm{M})$ and Untreated (cells without drug) for $72 \mathrm{~h}$. After the collection of cells washed twice with PBS and subjected to Annexin V and PI staining apoptosis KIT. After staining, analyze by flow cytometry after addition of PI immediately it has to be performed for the quantification of apoptotic and necrotic cells.

\section{TNF - alpha using Flow cytometry}

Six well plates cultured cell were taken with treatment EEC $(50 \mu \mathrm{g} / \mathrm{ml})$, standard Camptothecin $(75 \mu \mathrm{M})$, Untreated (A549cells) incubated at $37^{\circ} \mathrm{C}$ for $24 \mathrm{~h}$, Then wash with PBS, $0.5 \%$ BSA (bovine serum albumin) in 1X PBS (phosphate - buffered saline) and $0.1 \%$ sodium azide. Add $20 \mu 1$ of Anti p50 antibody, mix it thoroughly and incubate it for 30 minutes at room temperature $\left(20^{\circ}\right.$ to $\left.25^{\circ} \mathrm{C}\right)$. Analyze by flow cytometry immediately after addition of PI [10].

\section{NF-kB assay using Flow cytometry}

In a 6- well plate Culture cells consists at a density of $3 \times 10^{5}$ cells $/ 2 \mathrm{ml}$, the medium were treated with Untreated (cells without any drug, Standard (camptothecin $75 \mu \mathrm{M})$ and EEC $(50 \mu \mathrm{g} / \mathrm{ml})$ were incubated in a $\mathrm{CO}_{2}$ incubator overnight at $37^{\circ} \mathrm{C}$ for 24 hours. After treatment it was washed with PBS and $0.5 \%$ BSA in 1X PBS (phosphate - buffered saline) and $0.1 \%$ sodium azide. Add $20 \mu \mathrm{l}$ of Anti NFKB-FITC antibody, mix it thoroughly and incubate it for 30 minutes at room temperature $\left(20^{\circ}\right.$ to $\left.25^{\circ} \mathrm{C}\right)$. Analyze by flow cytometry immediately after addition of PI [11].

\section{Results and Discussion}

\section{Effect of Elaeagnus Conferta Roxb leaves on apoptosis in A549 cell line}

Crucial sort of cell demise is apoptosis and necrosis [12].Among from this precise action of cell demise is apoptosis. Approximately $40 \%$ of an abnormal mass of tissue undergo cell aberration in the apoptosis give on to abnormal cell proliferation. Act of apoptosis is an important fact in the cure of cancer. Many accumulated proof shows that the most chemotherapeutic agents stop tumor cell multiplication by means of enlistment of apoptosis [13]. Mainly apoptosis is distinguished by some morphological characteristics such as plasma membrane belbbing, cell shrinkage, condensation of the chromatin and cell disintegration into the apoptotic bodies. All these characteristics are the effects of the selective proteolysis involved in cell signalling, DNA repair, structural DNA integrity maintenance, caspase activation, cysteine- aspartate enzymes [14]. (Fig.1 and Fig.2).

\section{Control}

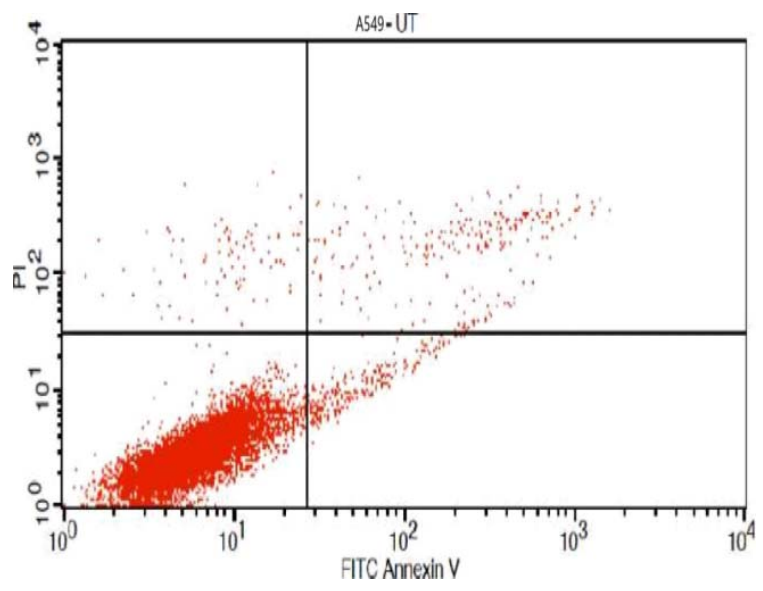




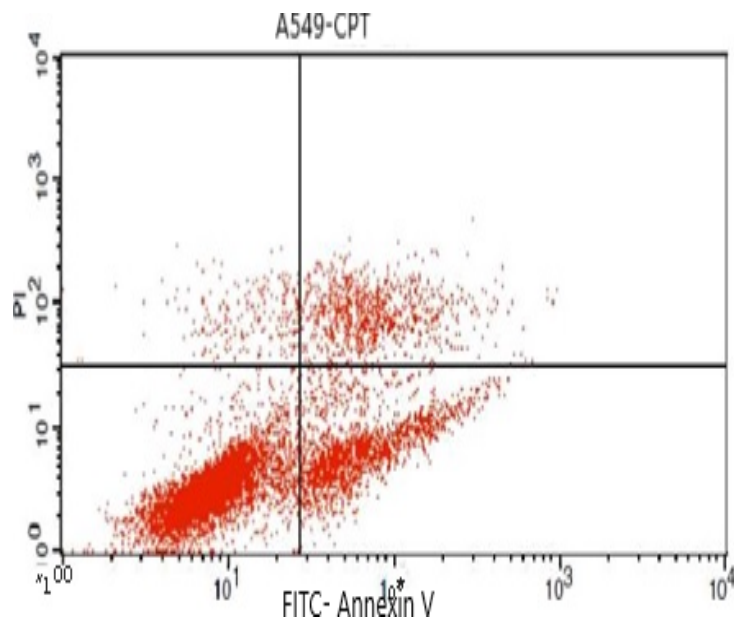

Standard

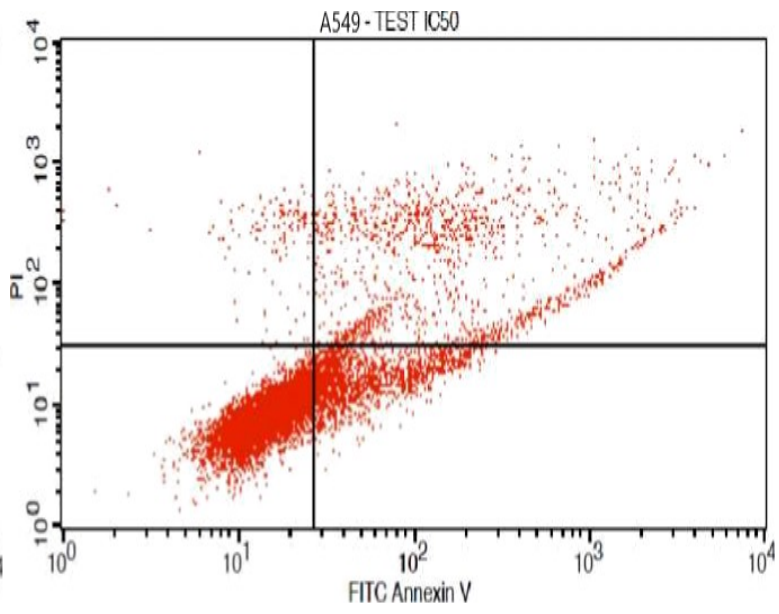

Treated with Elaeagnus conferta Roxb

Figure 1: Apoptosis induced by Elaeagnus conferta roxb in A549 cells

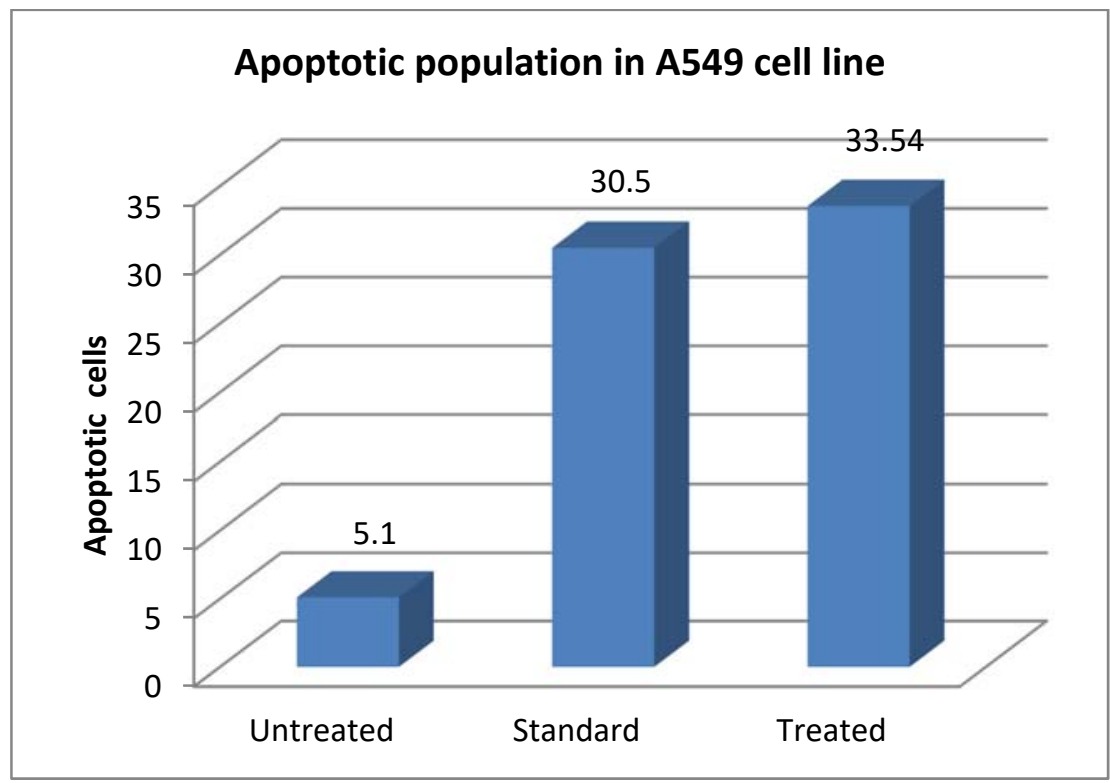

Figure 2: Apoptotic population cells in A549 cell line Data are expressed in as mean + standard deviation $(n=3)$

Apoptosis system convoluted in the pathway of inborn and extraneous, which was utilized to kill vigorously harmed cells, According to the report appeared by Bak et al. [15] apoptosis is the significant system used to kill malignancy cells is seen in essential apoptotic signalling pathways and their liberation in a cellular breakdown in the lungs. On the basic apoptosis, Sae-Bom Kwon et al. [16] observed, there was a release of mitochondrial cytochrome $\mathrm{C}$ into the cytoplasm of the cell on A549 malignancy cell line initiated by H9, it prompts the harm of the external film mitochondrial permeabilization which is fundamental to delivering cytochrome C. Chou et al. [17] observed on the release of the cytochrome $\mathrm{C}$ triggers caspase initiation in the execution pathway of apoptosis.

Tan et al. [18] gave an account of the apoptosis set off by two significant pathways (i.e., intrinsic and extrinsic) that assumes a fundamental part in cell development, endurance, advancement and tumorigenesis. Comparative outcomes were uncovered in our work there was an impact of apoptosis convince by Elaeagnus conferta Roxb leaves on A549 cells as there is seen adjusting the explanation levels of Bcl-2 proteins embedded in the mitochondrial layer, there is mitochondrial loss, release of cytochrome $\mathrm{C}$ in potential amount into cytosol, which sanctions caspase - 3 provoked the powerful enlistment of apoptosis. From this it reveals that Elaeagnus conferta Roxb leaves has antiproliferative and anticancer impacts on A549 malignancy cells as it indicated 33.54\% apoptotic cell contrasted with the standard $30.50 \%$. Henceforth this can be affirmed to have a potential for anticancer advantages through apoptosis. 


\section{TNF - alpha mediated apoptosis in A549 cells}

TNF $-\alpha$ is a powerful favorable to provocative cytokines associated with the edict of physiological and pathological process such as inflammation and tumor progression. It is a polypeptide mediator of an assortment of cell reactions, including apoptosis or necrotic cell lysis and expansion. Wang and Lin 2008 reported on TNF$\alpha$ mediated apoptosis though it has the capability to induce angiogenesis, proliferation, invasion and metastasis of tumor cells. As it was observed by annexin V and PI staining, treatment of A549 cells with TNF- $\alpha$ alone had apoptosis induced cell death at 2.0\%. The result was given in (Fig.3).

\section{Control}
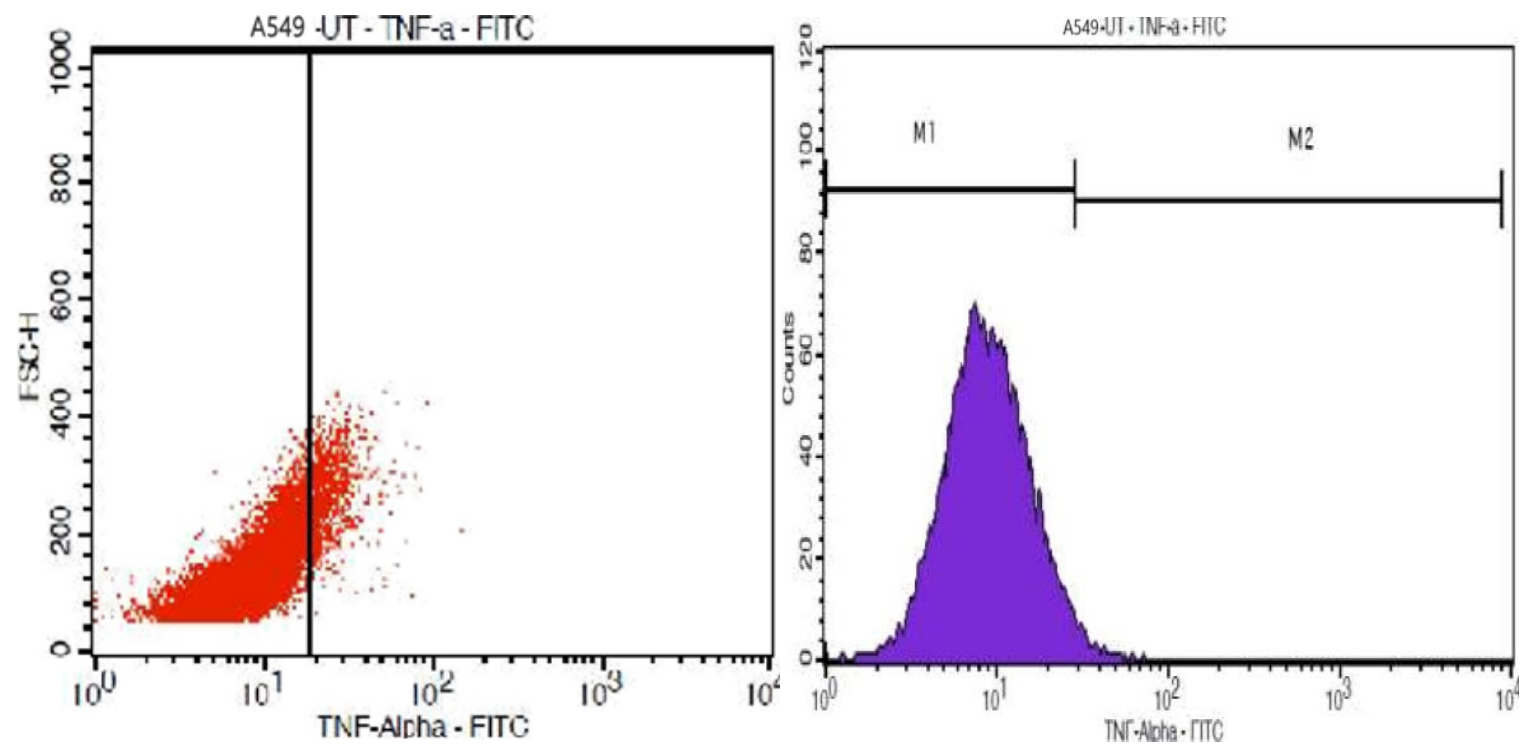

\section{Standard}
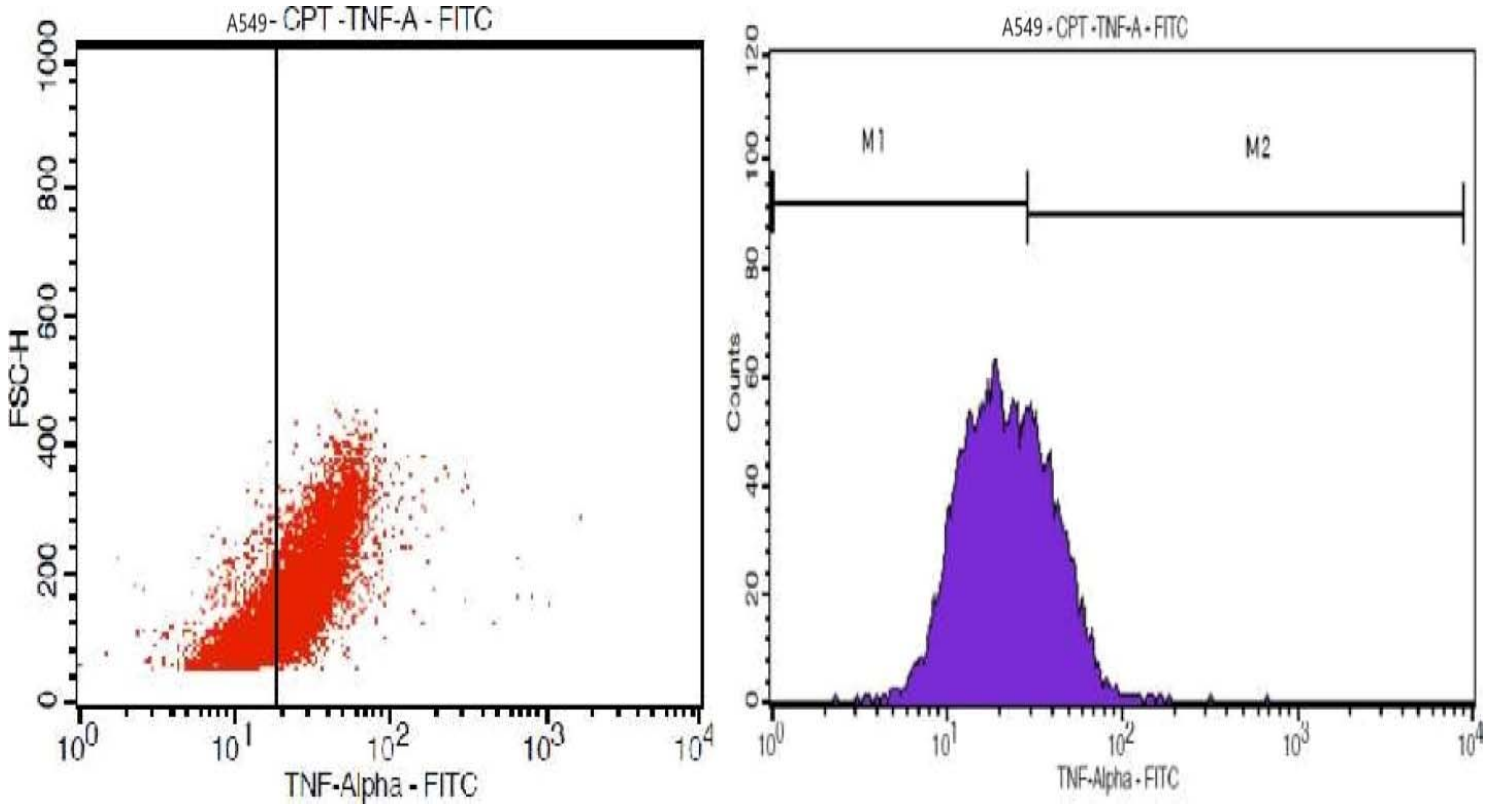


\section{Treated}
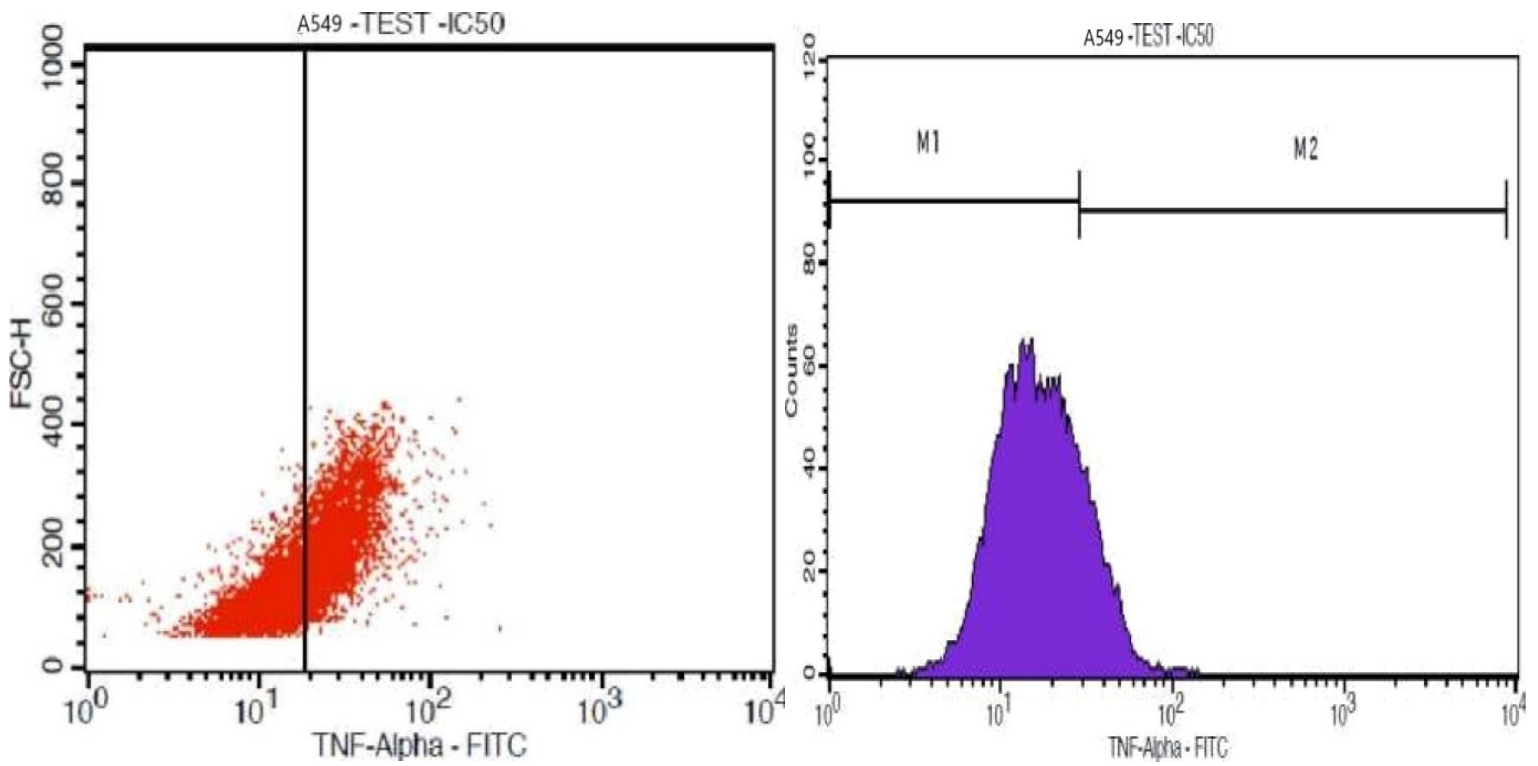

Figure 3: Flow cytometry analysis of TNF-alpha mediated apoptosis in A549 cells

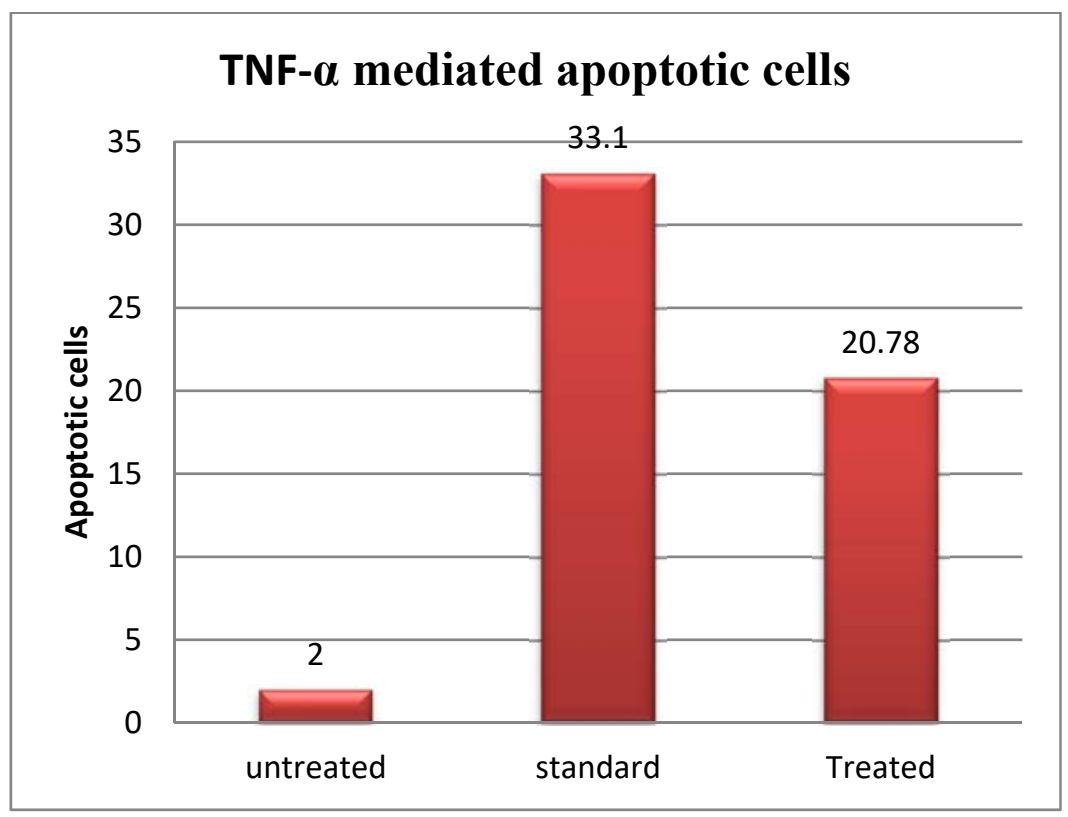

Figure 4: TNF- $\alpha$ mediated apoptotic cells in A549 cell line

However, pre-treatment of A549 cells with Elaeagnus conferta Roxb leaves followed by TNF- $\alpha$ caused the increased proportion of cells $(20.78 \%)$ at apoptosis induced cell death, which was statistically significant $(\mathrm{p}<$ 0.001 ) was given in (Fig.4). Therefore, it was observed from the result that Elaeagnus conferta Roxb leaves induce cell demise in A549 non small lung cancer cells via induction of apoptosis. Devin et al. [19] reported that TNF$\alpha$ have a great potential in linking the molecules correlated with inflammation and cancer. Whereas TNF $-\alpha$ is a cytokine it elicits various biological functions such as providing signals for activation, differentiation, survival and cell demise.

TNF- $\alpha$ take part in the process by binding itself to the Tumor necrosis factor R-1 (TNFR-1). Shang et al. [20] reported on the irrevocable of TNF- $\alpha$ with the TNFR-1, the receptor interacts with their respective domains for the programmed cell death involved with apoptosis. Perez-Gracia, [21] reported that patients with lung cancer found to express foremost of TNF- $\alpha$ in their serum level and take part in the widening of lung carcinoma. Huang et al. [22] observed in E2F1 protein is overexpressed in tumor proliferation on NSCLC (non- small cell lung cancer). Similar outcome was observed by Chayaporn Subkamkaew et al. [23] their work showed levels of TNF$\alpha$ is expelled in the tissues and serum samples in solid tumors. 
TNF- $\alpha$, there will seen down regulation of the antiapoptotic proteins which could enhance TNF- $\alpha$ induced cancer cell death through apoptosis. Accordingly, similar results revealed form this study the effect of Elaeagnus conferta Roxb leaves serves as an efficient agent that can suppress TNF- $\alpha$ induced cancer cell progression of A549 cancer cells, hence it could be an important part of an attractive and alternative form of cancer therapy.

\section{NF-kB expression in A549 cells}

NF-kB exerts an anti- apoptotic effect found in most cells. NF-kB modulates the proapoptotic effects of TNF$\alpha$ and facilitates the pro- inflammatory and proliferative effects of this cytokine. Biswas et al. [24] revealed that NF-kB is involved in pro- inflammatory cytokine secretion, anti- apoptotic gene expression and cell proliferation, though it was involved in immune defaults resulting in cancer as well as in chronic inflammatory diseases.

As to ascertain the modulatory effect of NF-kB in TNF- $\alpha$ induced cell death, the NF-kB expression was measured through flow cytometry. The result was given in the (Fig.5 and Fig.6). The untreated A549 cells had minimal NF-kB expression (0.25 $\pm 0.01 \%$ ). However, the treatment of A549 cells with Elaeagnus conferta Roxb had induced NF-kB production many fold $(11.50 \pm 1.05 \%)$.

\section{Control}
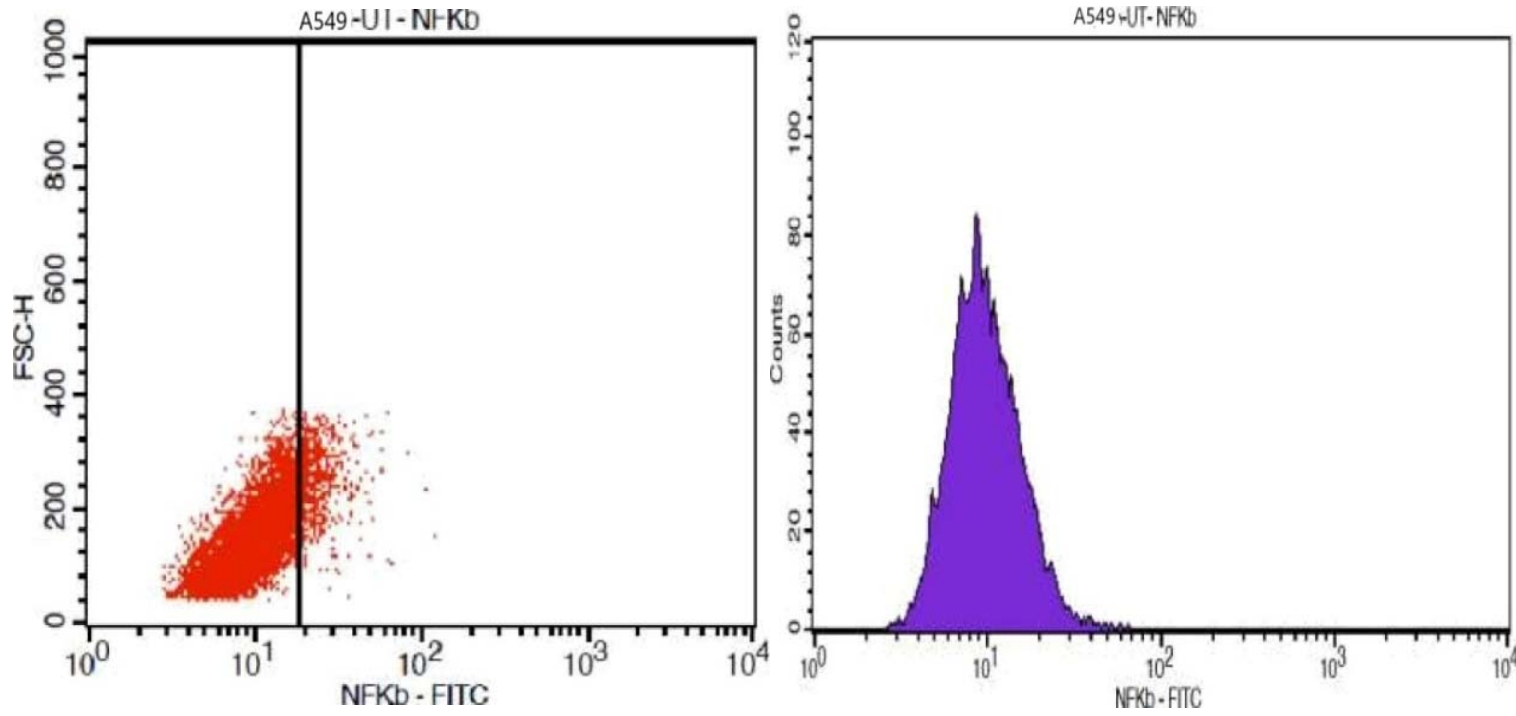

Standard
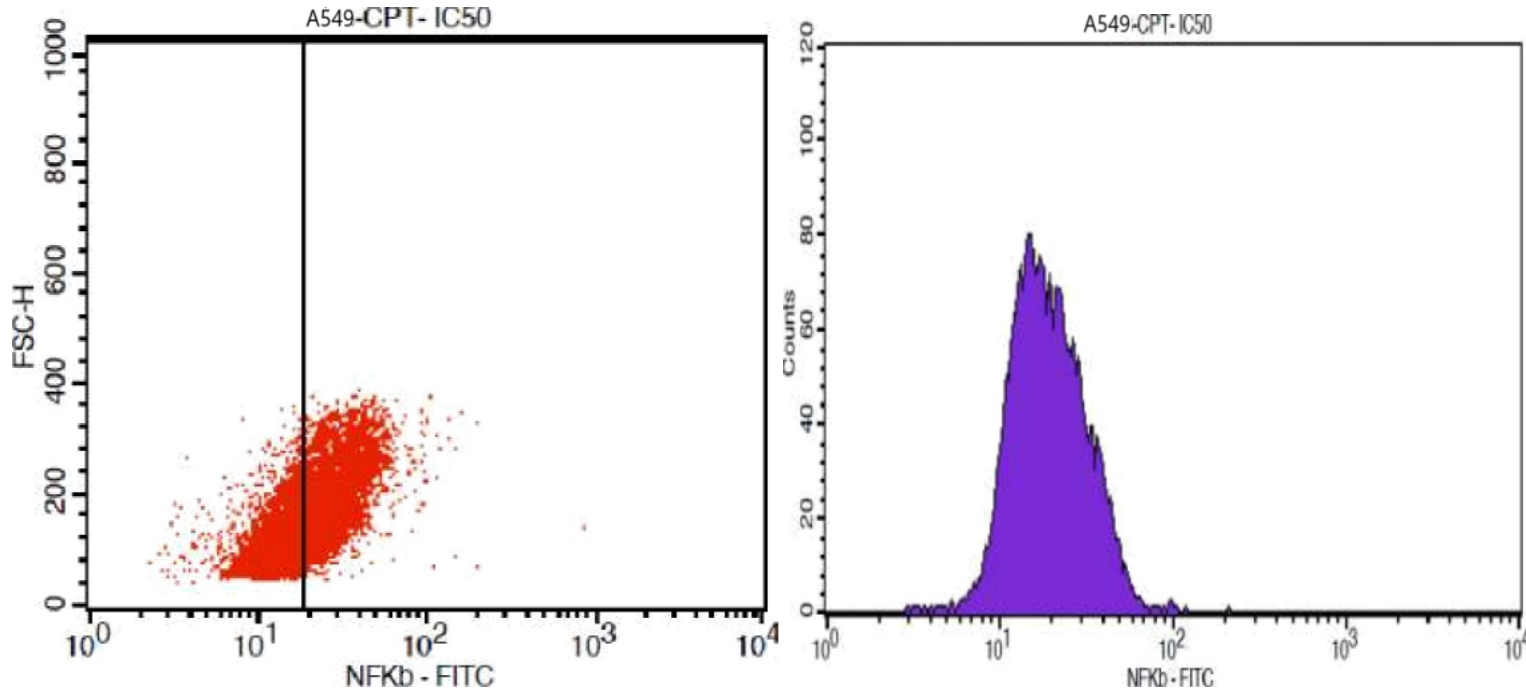


\section{Treated}
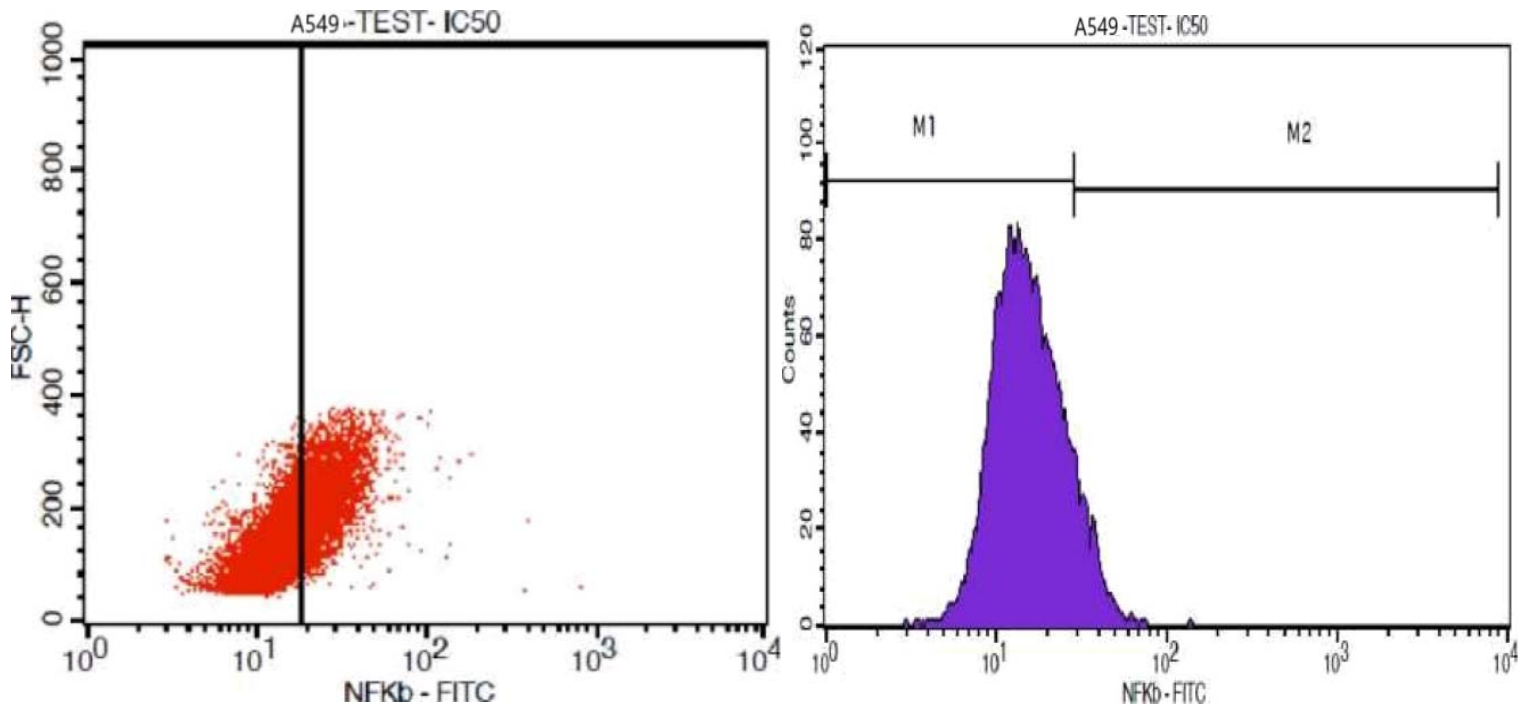

Figure 5: Flow cytometry analysis of NF-kB mediated apoptosis in A549 cells

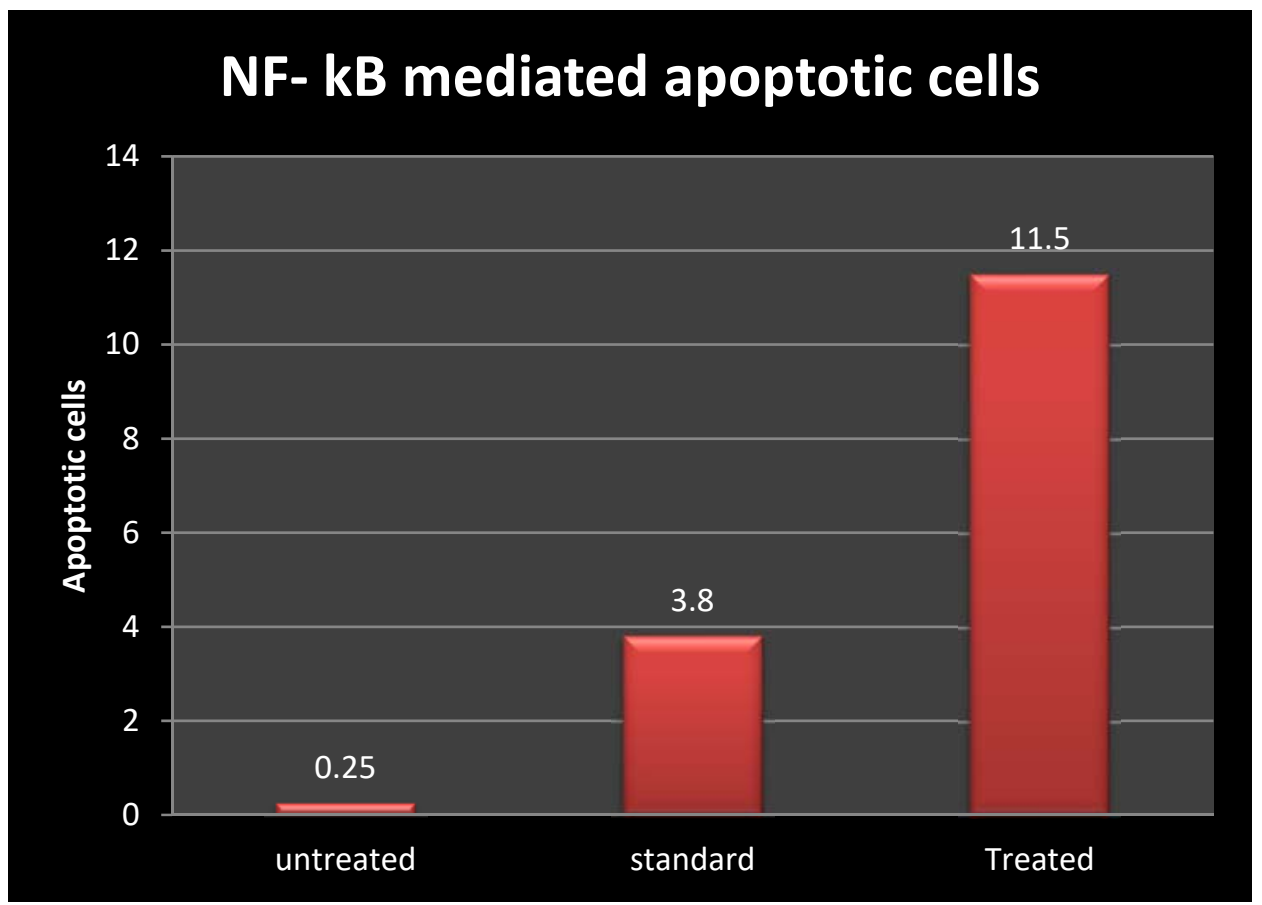

Figure 6: NF-kB mediated apoptotic cells

Many studies to the point have been reported on subduing of tumorigenesis in the lungs. Zhou et al. [25] reported on the over expression of NF-kB and TNF- $\alpha$ is increased in breast cancer. Yasuhisa Oida et al. [26] showed the findings about the NF-kB activation induced by Ad-mda7 in lung cancer, it shows hindrance of NF$\mathrm{kB}$ expression enhanced in killing of tumor cell. Similarly, Birsu Cincin et al. [27] revealed a study on hesperdidin had a greater suppressive on A549 and NCI - H358 cells. Ghorbani et al. [28] reported on hesperidin inhibits NF$\mathrm{kB}$ activation to trigger apoptosis in NALM -6 cells.

Mukogawa et al. [29] observed that inhibition of NF-kB has been manifest to increase the radiosensitivity in colon cancer cells. Likewise Sumitomo et al., 1999 reported on the study about cytokine producing cancer cells in bladder undergo apoptosis, there is a suppression of NF-kB activation [30]. Lambertini et al. [31] reported the in vitro anti- proliferative effect from $\mathrm{C}$. anthelminticum on human breast cancer cells, as it exhibits anti-oxidant property by inhibiting TNF- $\alpha$ induced human cancer cell growth by interrupting the activation of NF $-\mathrm{kB}$. Jones et al., 2000 worked on cell signaling pathway involves NF-kB activation as it was an important mechanism in chemoresistance in NSCLC [32]. These results show that NF-kB is activated in tumor cells by several mechanisms and its inhibition enhances treatment induced cell death. 


\section{Conclusion}

This present study has found the effect of Elaeagnus conferta Roxb leaves inhibits the cellular growth of non -small cell lung cancer A549 cells and induces apoptosis. Activation of NF-kB in response to inflammatory cytokine such as TNF- $\alpha$ promotes nuclear migration to enable DNA binding activity and facilitate to target gene expression. Therefore, it was convenient to conclude that the observed cytotoxic effect of Elaeagnus conferta Roxb on A549 cells was through induction of NF-kB, and modulation of TNF- $\alpha$ axis of the apoptotic cell demise path. Though the effect of Elaeagnus conferta Roxb leaves has the anticancer activity, further used to study its therapeutic margin before its role in usage.

\section{REFERENCES}

[1] P.Ragahavendra, A.G. Devi,T.B. Shyma. Investigations of anti-diabetic medicinal plants used by tribes of Wayanad district, Kerala. Int J Pharm sci Res., 2015, 6:3617-25.

[2] G.Lalitha,T.H. Nazeema.In vitro antioxidant activity and Fourier Transform Infrared Analysis of Elaeagnus conferta Roxb. Leaf extract. Asian J Pharm Clin Res., 2020, (13) 4: 50-53.

[3] R.L. Siegel, K.D. Miller, A. Jemal, Cancer statistics. 2016, Ca-Cancer J.,66: 7-30.

[4] Julie stockis, Rahul Roychoudhuri, Y.F. Timotheus, Halim. Regulation of regulatory T cells in cancer. Immunology.,2019, 157(3): 219231.

[5] M. De Groot Patricia, C.C. Wu, B.W. Carter, R.F. Munden. The epidemiology of lung cancer. Transl Lung Cancer Res.,. 2018, 7(3):220233. doi:10.21037/tlcr.2018.05.06. Bjorn Pasternak, Henrik Svanstrom, Torbjorn Callreus, Mads Melbye, Anders Hviid.Use of Angiotensin Receptor Blockers and the Risk of Cancer. Circulation., 2011,123:1729-1736.

[6] Y.Li, Y.Gong,L. Li, H.M. Abdolmaleky, J.R. Zhou. Bioactive tanshinone I inhibits the growth of lung cancer in part via downregulation of aurora a function. Mol. Carcinog., 2013,52: 535-543.

[7] X.Shan, D.Wang, J. Chen, X. Xiao, Y. Jiang, Y.Wang et al. Necrosis degree displayed in computed tomography images correlated with hypoxia and angiogenesis in breast cancer. J Comput Assist Tomogr., 2013, 37(1):22-8.

[8] Z.Wu, B. Liu, E. C.J. Liu, Q. Zhang, J. Liu, N.Chen, R. Chen, R. Zhu. Resveratrol inhibits the proliferation of human melanoma cells by inducing G1/S cell cycle arrest and apoptosis. Mol Med Rep., 2015, 11: 400-404.

[9] S.Zaman, R. Wang, V. Gandhi.Targeting the apoptosis pathway in hematologic malignancies. Leuk. Lymphoma., 2014, 55: $1980-1992$.

[10] J.Kim, S.Lee, J.Park et al. TNF- $\alpha$ induced ROS production triggering apoptosis is directly linked to Romo 1 and Bcl-XL. Cell death differ., 2010, 17: 1420- 1434.

[11] L.F. Wu, G.P.Li, J.D.Su, Z.J. Pu, J.L.Feng, Y.Q.Ye, B.L.Wei.Involvement of NF- kappaB activation in the apoptosis induced by extracellular adenosine in human hepatocellular carcinoma HepG2 cells.Biochem Cell Biol., 2010, 88(4):705- 14.

[12] Leist, Marcel and Jaattela, Marja. Caspase-independent cell death. First publ. in: Genetics of Apoptosis / Stefan Grimm (ed.) London : Taylor \& Francis., 2002, pp. 203-223

[13] Rasul, Azhar and Parveen, Saima and Ma, Tasneem,Costunolide: A Novel Anti-Cancer Sesquiterpene Lactone (Review). Bangladesh Journal of Pharmacology., 2012, 7: 6-13.

[14] S.W.Fesik. Promoting apoptosis as a strategy for cancer drug discovery. Nat. Rev. Cancer., 2005, 5: 876-885.

[15] Y.Bak, S. Ham, O.Baatartsogt,S.H. Jung, K.D.Choi, T.Y. Han et al.A1E inhibits proliferation and induces apoptosis in NCI-H460 lung cancer cells via extrinsic and intrinsic pathways. Mol. Biol. Rep., 2013, 40: 4507-4519.

[16] Sae-Bom Kwon, Min-Je Kim, Sun Young Ham, Ga Wan Park, Kang-Duk Choi , Seung Hyun Jung and Do-Young Yoon. H9 Induces Apoptosis via the Intrinsic Pathway in Non-Small-Cell Lung Cancer A549 Cells. J. Microbiol. Biotechnol., 2015, 25(3), 343-352

[17] S.H.Cho, K.S. Chung, J.H. Choi,D.H. Kim,K.T. Lee. Compound K, A metabolite of ginseng saponin, induces apoptosis via caspase-8dependent pathway in HL-60 human leukemia cells. BMC Cancer., 2009: 9: 449.

[18] M.L.Tan, J.P. Ooi, N.Ismail,A.I. Moad, T.S.Muhammad. Programmed cell death pathways and current antitumor targets. Pharm. Res.,2009, 26: 1547-1560.

[19] A.Devin, Y. Lin, Z.G. Liu. The role of the death-domain kinase RIP in tumour-necrosis-factor-induced activation of mitogen-activated protein kinases. EMBO Rep.,2003, 4, 623-627.

[20] G.S.Shang,L. Liu, Y.W.Qin. IL-6 and TNF-alpha promote metastasis of lung cancer by inducing epithelial-mesenchymal transition. Oncol. Lett., 2017, 13: 4657-4660.

[21] J.L.Perez-Gracia,C. Prior,F. Guillén-Grima,V. Segura,A. Gonzalez,A. Panizo, I. Melero, E.Grande-Pulido, A.Gurpide, I.Gil-Bazo. dentification of TNF- $\alpha$ and MMP-9 as potential baseline predictive serum markers of sunitinib activity in patients with renal cell carcinoma using a human cytokine array. Br. J. Cancer.,2009, 101, 1876.

[22] C.L.Huang, D. Liu, J. Nakano,H. Yokomise,M. Ueno,K. Kadota et al. E2F1 overexpression correlates with thymidylate synthase and survivin gene expressions and tumor proliferation in non small-cell lung cancer. Clin Cancer Res., 2007: 13:6938-46

[23] Chayaporn Subkamkaew, Pornngarm Limtrakul (Dejkriengkraikul) and Supachai Yodkeeree. Proanthocyanidin-Rich Fractions from Red Rice Extract Enhance TNF- $\alpha$-Induced Cell Death and Suppress Invasion of Human Lung Adenocarcinoma Cell A549. Molecules., 2019,24, 3393;1-15.

[24] Amit Kumer Biswas, Md Reazul Islam, Zahid Sadek Choudhury, Asif Mostafa and Mohammad Fahim Kadir, Nanotechnology based approaches in cancer therapeutics. Adv. Nat. Sci.: Nanosci. Nanotechnol., 2014, $5: 1-12$.

[25] X.L. Zhou, W. Fan, G.Yang,M.X. Yu. The clinical significance of PR, ER, NF- kappa B, and TNF- alpha in breast cancer. Dis Markers., 2014; 2014:494581.

[26] Yasuhisa Oida, Began Gopalan, Ryo Miyahara, D. Cynthia, Branch, Paul Chiao, Sunil Chada, Rajagopal Ramesh.Inhibition of nuclear factor-KB augments antitumor activity of adenovirus-mediated melanoma differentiationassociated gene-7 against lung cancer cells via mitogen-activated protein kinase kinase kinase 1 activation. Mol Cancer Ther., 2007, 6(4):1440-9.

[27] Z.Birsu Cincin,M. Unlu,B. Kiran,E. Sinem Bireller, Y.Baran, B. Cakmakoglu. Anti-proliferative, apoptotic and signal transduction effects of hesperidin in non-small cell lung cancer cells. Cell Oncol., 2015, (Dordr) 38: 195-204.

[28] A.Ghorbani, M. Nazari, M. Jeddi-Tehrani,H. Zand. The citrus flavonoid hesperidin induces p53 and inhibits NF-kB activation in order to trigger apoptosis in NALM-6 cells: Involvement of PPAR $\gamma$-dependent mechanism. Eur J Nutr., 2012,51: 39-46. 
[29] T.Mukogawa, F. Koyama,M. Tachibana et al. Adenovirus-mediated gene transduction of truncated IkB $\alpha$ enhances radiosensitivity in human colon cancer cells. Cancer Sci., 2003,94:745-50. 14.

[30] M.Sumitomo, M.Tachibana,C. Ozu, et al. Induction of apoptosis of cytokine-producing bladder cancer cells by adenovirus-mediated IkB $\alpha$ overexpression. Hum Gene Ther., 1999, 10:37-47.

[31] Lambertini, Elisabetta and Piva, Roberta and Khan, Mahumud Tareq Hassan and Lampronti, Ilaria and Bianchi, Nicoletta and Borgatti, Monica and Gambari and Roberto. Effects of extracts from Bangaladeshi medicinal plants on in vitro proliferation of human breast cancer cell lines and expression of estrogen receptor alpha gene. Int. J oncology., 2004, 21: 419- 23.

[32] David R Jones, R.Michael Broad,V. Lee,B.S. Madrid. Albert S Baldwin and Marty W Mayo. Inhibition of NF-kB sensitizes Non- small cell lung cancer cells to chemotherapy- Induced Apoptosis. Ann Thorac Surg.,2000, 70:930-7. 